\title{
Tat Twam Asi Based Role-Playing Learning Model in Social Studies Knowledge Competence
}

\author{
Kadek Dwi Intan Agustini ${ }^{1 *}$, I Made Suarjana ${ }^{2}$ I Nyoman Laba Jayanta ${ }^{3}$ Ndara Tanggu Renda ${ }^{4}$
}

${ }^{1234}$ Elementary School Teacher Education Study Program, FIP, Undiksha, Indonesia

\section{ARTICLEINFO}

\section{Article history:}

Received 18 March 2020

Received in revised form 30 April 2020

Accepted 5 May 2020

Available online 15 May 2020

\section{kata kunci:}

role-playing, tat twam

asi

keywords:

role-playing, tat twam asi

\begin{abstract}
A B S T R A K
Rendahnya kompetensi pengetahuan IPS yang dimiliki siswa akibat kurang aktifnya siswa dalam proses pembelajaran, hal ini menjadi salah satu alasan penelitian ini dilakukan. Tujuan penelitian ini adalah untuk mengetahui pengaruh model pembelajaran Role-Playing berbasi Tat Twam Asi terhadap penguasaan kompetensi pengetahuan IPS. Penelitian ini merupakan penelitian quasi experiment dengan desain nonequivalent post-test only control group. Populasi dalam penelitian ini adalah seluruh kelas V SD Gugus IV Kecamatan Buleleng Kabupaten Buleleng yang berjumlah 5 kelas dengan jumlah 172 siswa. Sampel dalam penelitian ini yaitu SD Negeri 1 Banyuasri sebagai kelompok eksperimen dengan jumlah 35 siswa dan SD Negeri 5 Banyuasri sebagai kelompok kontrol yang berjumlah 32 siswa yang diambil dengan teknik group desain random sampling. Pengumpulan data kompetensi pengetahuan IPS dilakukan dengan menggunakan tes
\end{abstract} pilihan ganda. Data dianalisis dengan statistik deskriptif dan statistik inferensial yaitu uji $t$-test polled varians. Setelah menganalisis data diperoleh thitung sebesar 8,99 sedangkan t-table sebesar 3,99, sehingga thitung lebih besar daripada t-table. Hal ini menunjukan bahwa terdapat perbedaan penguasaan kompetensi pengetahuan IPS antara kelompok eksperimen dan kelompok kontrol. Berdasarkan temuan tersebut dapat disimpulkan bahwa model pembelajaran Role-Playing berbasis Tat Twam Asi berpengaruh signifikan terhadap penguasaan kompetensi pengetahuan IPS. Model ini bisa dijadikan pilihan oleh guru sebagai alternatif dalam kegiatan proses pembelajaran untuk mencapai tujuan pembelajaran yang diharapkan.

\section{A B S T R A C T}

The low competence of Social Studies knowledge possessed by students due to lack of active students in the learning process. This is one of the reasons this research was conducted. This study aimed at examining the impact of Tat Twam Asi based Role-Playing learning model on the mastery of Social Studies competence. This was a quasi-experiment study and the design was an on-equivalent post-test only control group. The population in this study were all grade V of Gugus IV elementary school Buleleng Sub-district, Buleleng regency, amounting to 5 classes with a total of 172 students. The samples were students of SD Negeri 1 Banyuasri as an experimental group with a total of 35 students and SD Negeri 5 Banyuasri as a control group of 32 students determined by applying group design random sampling technique. Data on the competence of Social Studies knowledge were collected by using multiple-choice tests. Descriptive statistics and inferential statistics are t-tests polled variants were applied in analyzing them. After analyzing the data, the $t$-count is 8,99 while the $t$-table is 3.99 , so the $\mathrm{t}$-count is greater than the $\mathrm{t}$-table. This shows that there are differences in the mastery of IPS knowledge competence between the experimental group and the control group. Based on the findings, it could be concluded that Tat Twam Asi based role play learning model had a significant impact on the mastery of Social Studies knowledge competence. This model can be chosen by the teacher as an alternative in the learning process activities to achieve the expected learning objectives.

Copyright (c) Universitas Pendidikan Ganesha. All rights reserved.

\footnotetext{
${ }^{1}$ Corresponding author.
}

E-mail addresses: intanagustini869@gmail.com¹ㄴ. (Intan), imade.suarjana@undiksha.ac.id² (Suarjana), laba.jayanta@undiksha.ac.id³ (Laba) ndaratanggu.renda@undiksha.ac.id4 (Ndara) 


\section{Introduction}

One of the subjects that can provide knowledge and social skills to students in social studies. Social Studies are various disciplines that are integrated and related to humans and their environment (Kristin, 2018). Social Studies (IPS) subjects must be taught at every level. In elementary schools to secondary schools, one subject is given, namely IPS which examines material about all events, facts, concepts, and generalizations related to community problems (Meiyani, 2017). Social studies learning in schools focuses on everything related to human life and its problems because as explained by Antari (2017) Social Studies is the study of humanities and Social Studies disciplines related to human life to provide understanding and insight for students at various levels. Social studies are one of the thematic subjects combined from various elements such as history, geography, economics, law and politics, sociology, citizenship, education and religion, and the humanities field (Indrawan, 2017). In elementary school, the content of social studies material in learning is not only aimed at providing knowledge but is oriented to the development of student attitude skills (Rahmawati, et al, 2016).

Student attitude skills will be developed in social studies learning in accordance with the objectives of social studies subjects presented by Trianto (2012), namely the objectives of social studies are expected to be able to develop the potential of students so that students have a sensitivity to various social problems in the community, contribute to helping correct all inequalities that occur, and readily solve the problems that occur, both problems of oneself or society (Trianto, 2012). And according to Surahman and Mukminan (2017) IPS in education is a concept that aims to develop knowledge, attitudes, and social skills in the context of forming and developing citizens to be good individuals in accordance with Pancasila and the 1945 Constitution, this has also been being part of the curriculum and education system discourse in Indonesia and is a social education program in the path of school education. Social studies education in schools as integrated subjects that social studies learning programs is arranged from various branches of Social Studies (Setiana, 2014). This is also supported by the opinion of Emin (2014: 416) which states that "social studies is the integrated study of Social Studies and humanities to promote civic competence". Social studies learning in an integrated manner is very important to encourage mutual understanding between human beings, and the focus of attention on human relations with social understanding (Parbawa, et al, 2018). Along with the times when there is a change in the structure of people's lives, with social studies learning students are expected to be able to understand and be able to adjust themselves to changes that often occur in society (Santiasih, 2016). Social studies learning in elementary schools is expected to create a pleasant atmosphere for students.

But the reality of social studies learning so far is learning that does not pay attention to the pleasant atmosphere for students, the learning process is monotonous and does not pay attention to the characteristics of students as well as a lot of social studies learning material, resulting in mastering the competence of Social Studies knowledge competence in students (Parbawa, et al, 2018). The influence of Social Studies knowledge competency can be proven from several research results that have been carried out such as research conducted by Leoniari, et al (2018) stating students' abilities in the field of social studies are influenced by the use of appropriate learning models. In addition, research conducted by Lestari (2019) also states that there is an influence between the uses of learning models with the mastery of students' Social Studies knowledge competencies. The fact of the results of the study also occurred in the Cluster IV Public School, Buleleng District, Buleleng Regency.

This was supported by the results of interviews, observations and documentation studies conducted at Cluster IV Public Schools, Buleleng District, Buleleng Regency on October 21-October 26, 2019 to social studies teachers about problems that occur in the learning process in the interview activities involving teachers social studies teacher to find out the problems that occur in government schools in Cluster IV, Buleleng District, Buleleng Regency. As for the results of interviews with fifthgrade teachers as follows: (1) in the learning process of students lacking enthusiasm, this is because the learning material described is too much, (2) in the learning process the use of media is not optimal due to the availability of learning media limited to school, and (3) group learning in the class has not run optimally because student discipline is still lacking in the work given by the teacher so that other students feel disturbed, and (4) there are still many students who do not want to help their friends in helping to understand learning material and the lack of tolerance among students when their friends incorrectly answer the teacher's questions, causing students to disagree with each other.

Furthermore, observations in class when social studies were taught, there were problems such as: (1) in learning activities in the classroom most are still teacher-centered because this is still using the lecture method in providing material by the teacher so that students feel bored and inclined ignoring the teacher's explanation, (2) students 'understanding of social studies learning material is 
lacking, which results in students' Social Studies knowledge competence is still low, it is because teachers do not use teaching aids to facilitate student understanding, (3) student communication during group discussions is still low cause because students are less active in-class discussion activities provided by the teacher which results in group discussions not being able to run optimally, and (4) in the learning process, when students incorrectly answer the teacher's questions other students mock him and don't want to help teach him or don't want fix errors that tel ah made by his friend, so some students feel intimidated by friends who have more abilities. Thematic learning with social studies carried out by teachers is still not optimal and this influences the mastery of students' Social Studies competency knowledge (Astami, et al, 2016). This is also supported by the results of documentation studies that have been carried out.

The results of the documentation study of the results of the acquisition of midterm exams (UTS) The results of the acquisition of midterm exams (UTS) in the State School Cluster IV Buleleng District fifth grade students are as follows.

Tabel 1. Average Values of Social Studies of Fifth Grade Students Sekolah Negeri Gugus IV Kecamatan Buleleng 2019/2020 Academic Year

\begin{tabular}{|c|c|c|c|c|c|c|c|}
\hline \multirow{2}{*}{\multicolumn{2}{|c|}{ No. Nama Sekolah }} & \multirow{2}{*}{$\begin{array}{l}\text { Jumlah } \\
\text { Siswa }\end{array}$} & \multirow[t]{2}{*}{ KKM } & \multicolumn{2}{|c|}{$\begin{array}{c}\text { Siswa yang } \\
\text { mencapai KKM }\end{array}$} & \multicolumn{2}{|c|}{$\begin{array}{l}\text { Siswa yang belum } \\
\text { mencapai KKM }\end{array}$} \\
\hline & & & & Siswa & $\%$ & Siswa & $\%$ \\
\hline 1 & SD Negeri 1 Banyuasri & 35 & 75 & 23 orang & 65,71 & 12 orang & 34,29 \\
\hline 2 & SD Negeri 2 Banyuasri & 41 & 75 & 31 orang & 75,61 & 10 orang & 24,39 \\
\hline 3 & SD Negeri 3 Banyuasri & 30 & 75 & 25 orang & 83,33 & 5 orang & 16,67 \\
\hline 4 & SD Negeri 4 Banyuasri & 34 & 75 & 22 orang & 64,71 & 12 orang & 35,29 \\
\hline \multirow[t]{2}{*}{5} & SD Negeri 5 Banyuasri & 32 & 75 & 20 orang & 62,50 & 12 orang & 37,50 \\
\hline & Jumlah & 172 & - & 121 & 70,35 & 51 orang & 29,65 \\
\hline
\end{tabular}

(Sumber: Wali Kelas V Sekolah Negeri Gugus IV Kecamatan Buleleng)

Based on table 1, in the School Group of Cluster IV Buleleng District totaling 172 students in class $\mathrm{V}$, there are still 51 students or equal to $29.65 \%$ who have not reached the KKM, this is a problem that must be addressed. Thus, this indicates a lack of social spirit and has the desire to help others in students, because helping others is the same as helping themselves. If this is not resolved immediately, there will continue to be a decrease in the mastery of Social Studies knowledge competencies and will indirectly affect student relations with students, teachers with students or the scope of relations with society at large will not be good. To overcome this need to use the right learning model. The learning model that can be used to overcome these problems is one of them is a Role-Playing learning model based on Tat Twam Asi.

The Role-Playing learning model is one of the mastery models of learning materials through the development of the imagination and appreciation of students in the world of education (Subagiyo, 2013). According to Shoimin (2014), Role-Playing makes students play a role to increase student awareness of the values contained in a manuscript. According to Mulyani (2016), Role-Playing is something that has never been heard by children, with the imagination that children have makes these activities look very exciting with the world that children make themselves. According to research from Dewi (2017), the Role-Playing model is a learning model that directly involves all students in the learning process and is very suitable for use in learning material about the problems being faced by students' social environment. The Role-Playing learning model is a model that can be used in the classroom because it is interesting for students, and can play characters in historical events of past events (Kristin, 2018). According to Mardalena's research (2018), the Role-Playing learning model is acting in accordance with the characters he gets to achieve certain goals. Wahyuni's research (2016) the use of Role-Playing learning models is one of the efforts that must be made in improving students' abilities, such as choosing and using approaches, strategies, methods, and models of learning, techniques that are appropriate to the situation and conditions of students. Basri Research (2017) Role-Playing is mastery of learning material with students' appreciation and imagination development. According to Nurbiyanti's research (2017), the Role-Playing learning model is a learning model carried out by understanding all subject matter through the imagination and appreciation of students by diving certain characters with other friends. From this description, it can be said that with the RolePlaying learning model students become more active because learning is done in groups by understanding all the subject matter through the imagination and appreciation of students by acting certain characters based on drama scripts that have been prepared by the teacher. 
This Role-Playing learning model has advantages compared to other learning models, Shoimin (2014) formulates the advantages of Role-Playing learning models, namely: 1) can understand events that take place easily and can pick the points of wisdom contained therein with the appreciation of students themselves, 2) play activities are activities that are easy to use in several different situations, 3) evaluations can be made by the teacher observing when students are implementing the game, 4) students are free to make decisions and express themselves in full, 5) activities can attract students so that the class becomes active, 6) has a long-lasting memory on students, 7) fosters self-confidence and a sense of solidarity and social solidarity, and 8) is possible to enhance students' professional abilities, and can foster/open opportunities for employment. Furthermore, the advantage of Role-Playing models according to Djamarah (2013) is that it can train students to understand and remember the contents of the material being played, students will practice to initiate and be creative, the talent contained in students can be fostered so that it is possible to emerge or grow the seeds of drama art in school, cooperation between players can be fostered and fostered as well as possible, students get the habit of accepting and sharing responsibility with others, the students' spoken language can be fostered into a better language so that it is easily understood by others. Next, the steps of the RolePlaying learning model (Mulyadi, 2011), namely: 1) the teacher prepares a scenario, 2) appoint several students to study the scenario, 3) group formation, 4) provides an explanation of the competencies to be achieved, 5) instructs students scenarios that have been learned, 6) students pay attention to the appearance of their friends, 7) assigning scores to each other group performances, 8) delivering conclusions, 9) confirmation of the teacher of the learning process that has been going on, 10) evaluation and 11) closing.

This is supported by several studies that have been carried out and focused on mastering the competencies of Social Studies knowledge using the Role-Playing learning model including (1) research conducted by Budi (2016) there is a positive influence on the social attitudes of groups of students who take media-assisted Role-Playing learning models. satua Bali is compared with groups of students who take conventional learning and there is a positive influence on understanding the concept of PPKn between groups of students who follow the Role-Playing learning model assisted by satua Bali media compared to groups of students who take conventional learning, (2) research conducted by Evie (2017 ) the use of Role-Playing learning models assisted by media masks influences the mastery of Social Studies competence in class V SDN Cluster Tuanku Imam Bonjol, West Denpasar District, (3) research conducted by Lestari (2019) host of concrete media influences the knowledge competence of social studies students in class IV SD III Cluster North Kuta District Academic Year 2018/2019, and (4) Research conducted by Widnyana, et al (2017) in class IV SDU Untung Surapati clusters in East Denpasar District 2016/2017 there is an influence of the Role-Playing learning model based on Tri Hita Karana on the Social Studies competence of fourth grade students of the Untung Surapati Cluster Elementary School, Denpasar Timur District, 2016/2017 Academic Year. Based on the results of previous studies conducted it can be concluded that the Role-Playing model has a significant influence on the mastery of students' Social Studies knowledge competence.

So that the learning process can run optimally, it needs to be combined with the values of local wisdom, one of which is the teaching of tat twam asi. Hinduism teaches the value of Tat Twam Asi, which means: I am you, you are me. In Sanskrit according to Juniani (2019), tat twam asi consists of three syllables. Based on this, the teaching of tat twam asi is the teaching which means I am you and you are me who is applied in the learning process. It is expected that students do not discriminate between friends, respect differences, and be mutual tolerance so that all learning processes can be interpreted properly. This is also supported by the opinion of Pradnyani (2017) on the fourth-grade students of the PB Cluster Elementary School. Sudirman Denpasar Barat Academic year 2016/2017 using Quantum learning based on local wisdom Tat Twam Asi affects the competency of students' PKN knowledge. Thus, this supports that the use of Tat Twam Asi in learning can increase the expected competence of knowledge and changes in student behavior in a better direction.

Based on this, if the use of Tat Twam Asi based Role-Playing learning models will be integrated into better learning because in principle in social studies learning, students are expected to have good knowledge, attitudes, and skills in the social environment. Tat Twam Asi Role-Playing learning model has syntax according to Kurniasih (2017) is 1) preparation of scenario text preparation that will be used in Tat Twam Asi based Role-Playing models by teachers, 2) prepare all students to learn the scenarios that have been made, 3) the formation of student groups, 4) providing an explanation of the competencies that must be achieved, 5) designating one of the groups to display the scenarios that have been studied, 6) each group examines the contents of the scenario text and paying attention to their friends who appear in front of the class, 7) each group a paper was given to evaluate each group's performance, and 8) each group concluded. The teaching of Tat Twam Asi guides us to have a social 
spirit and have the desire to help others in students because helping others is the same as helping ourselves (Juniani, 2019). According to Adhi (2016), the teaching of Tat Twam Asi is the soul of social philosophy and is also the basis of the Hindu moral code of conduct in social karma, which is depicted with immorality, good and noble behavior that is used to foster harmonious relations between fellow creatures of God, so humans need to know and carry out a sense of belonging, so that how heavy whatever problems they face will feel light, by understanding and practicing the teachings of Tat Twam Asi. This has a positive influence on fellow students in the learning process to help each other understand the learning material taught by the teacher so that the mastery of students' knowledge competencies will be further increased. So, to be able to improve the mastery of Social Studies knowledge competencies of students who have a high social spirit and help one another, the use of Tat Twam Asi based Role-Playing learning models is appropriate.

The use of the Role-Playing learning model based on Tat Twam Asi certainly can make students in the learning process become more active and create a good relationship between students and students or teachers so that it is expected to influence the mastery of Social Studies knowledge competencies. This is in line with research conducted by Adnyana, et al (2017) stating that the Tat Twam-based Role-Playing learning model influences the mastery of IPS knowledge competency because, based on the descriptive statistical analysis results of IPS science competency in the experimental group, the average gain score $=75,72$. And the control group obtained an average gain score $=63,66$, so it can be concluded that in this study the Tat Twam Asi Based Role-Playing model influences the competence of IPS knowledge. Furthermore, research conducted by Widnyana (2017) on the fourth-grade students of the Untung Surapati Cluster Elementary School in East Denpasar District in the 2016/2017 school year based on the results of data analysis was obtained as follows. 1) obtained $\mathrm{t}$-count $=8.315>\mathrm{t}$-table $=2,000$ for the significance of $5 \%$ and $\mathrm{dk}=75$ so that $\mathrm{H} 0$ is rejected and $\mathrm{Ha}$ is accepted, 2) the average value of Social Studies knowledge competence in the group learned with the Role-Playing learning model based on Tri Hita Karana is 84, 31, while in the group that was taught with conventional learning was 69.11, thus it can be concluded that there is an effect of the Role-Playing learning model based on Tri Hita Karana on the competence of Social Studies knowledge. Also supported by research conducted by Pradnyani (2017) states that the average score of experimental group learning outcomes learned using Quantum learning models based on local wisdom Tat Twam Asi is higher than the average score of learning outcomes with conventional learning, besides, there is a change in attitude in students who are taught using the Tat Twam Asi based learning model as students become accustomed to helping their friends who have difficulty understanding learning material. So the learning model of the learning cycle based on Tat Twam Asi has a positive effect on the mastery of students' Social Studies knowledge competence.

Based on the description above, the use of the Tat Twam Asi based Role-Playing learning model theoretically influences students' Social Studies knowledge competence. Furthermore, to measure the magnitude of the influence empirically, a study entitled "The Effect of Tat Twam-Based Role-Playing Learning Model on Mastery of Social Studies Knowledge Competence of Fifth Grade Students in Cluster State Schools, Buleleng District, Buleleng Regency Academic Year 2019/2020".

The objectives to be achieved in this research are to find out the significant influence of the Tat Twam Asi Based Role-Playing learning model on the Mastery of Social Studies Knowledge Competence of Fifth Grade Students in Cluster Public Schools, Buleleng District, Buleleng Regency Academic Year 2019/2020. The research conducted uses more recent learning materials in accordance with the 2013 curriculum with 30 tests given to students compared to previous studies that only used 20 test questions.

\section{Method}

The setting of this research was in the Cluster IV Public School Buleleng District, Buleleng Regency in grade V elementary school students in the academic year 2019/2020 which ran from 27 February 2020 to 16 March 2020. This type of research was a quasi-experimental research with the research design used was nonequivalent post-test only control group design. The purpose of the nonequivalent post-test only control group design was that random only applies to determine the experimental group and the control group of the population and only using the post-test in the experimental group and the control group at the end of the study. The results of the post-test of the two groups would be compared to determine the effect of the treatment given to the mastery of students' social science knowledge competence in the cognitive domain. The quasi-experimental research design with a non-equivalent design post-test only controls group design is presented as follows. 
Tabel 2. Experimental Design Non-Equivalent Post-Test Only Control Group Design

\begin{tabular}{ccc}
\hline Kelas & Treatment & Post-test \\
\hline $\mathrm{E}$ & $\mathrm{X}$ & 01 \\
$\mathrm{~K}$ & - & 02 \\
\hline
\end{tabular}

(Sources: Dantes, 2017:17)

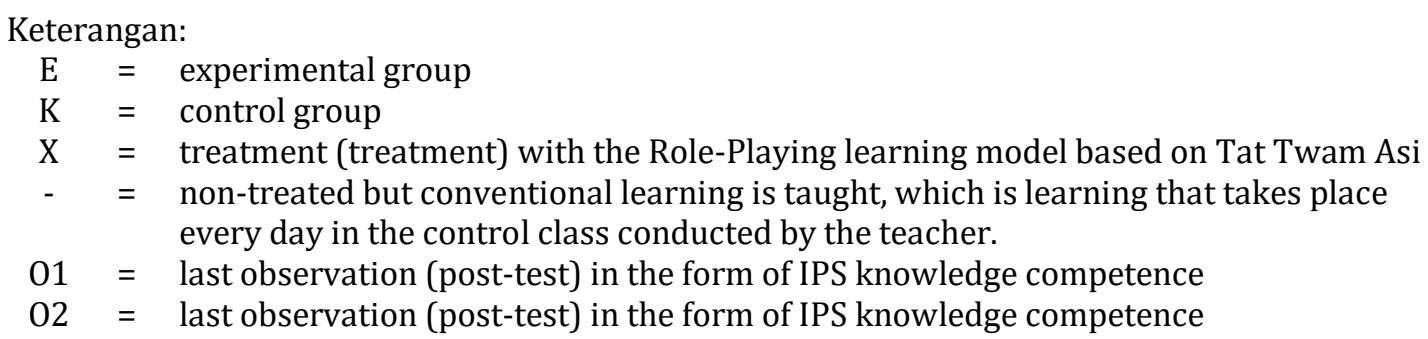

According to Sugiyono (2014), a population is a group of objects or subjects that are determined by researchers to have certain qualities and characteristics to conclude. The population in this study was all fifth grade Cluster IV State Schools, Buleleng District, Buleleng Regency Academic Year 2019/2020 which still applied the 2013 Curriculum. Students whose data will be tested for equality in all public schools in Cluster IV Buleleng District to determine the research sample. Riduwan (2011) sample is part of the population-representative to be studied. The research sample is the source of data taken from a portion of the population that represents the entire population. Furthermore, Sugiyono (2014) sample is the part that is owned by the population. This study involved two fifth grade public schools as a research sample, namely one experimental class and one control class. The use of samples in this study is random sampling. Random sampling is used as a sampling technique because all individuals in this population are already distributed into classes so that it is not possible to randomize all individuals in the population. Then the draw is made to determine the research sample. The draw results obtained were fifth grade SD N 1 Banyuasri totaling 35 people as the experimental class and fifth grade SD N 5 Banyuasri totaling 32 people as the control class.

This study uses one type of data collection method, the test method. The test method used is a multiple-choice test on the competence of Social Studies knowledge totaling 30 items compiled and developed based on social studies subject matter according to the syllabus of fifth-grade social studies the second semester with Theme 6 (Heat and Dissemination) and Theme 7 (Events in Life) which elaborated in the grid of knowledge competency results made based on basic competencies (KD), namely KD 3.2 analyzes the forms of human interaction with the environment and their influence on the social, cultural, and economic development of Indonesian society and KD 3.4 namely identifying important factors causing the nation's occupation Indonesia and the efforts of the Indonesian people in maintaining their sovereignty. This test reveals students' mastery of learning outcomes in the form of Social Studies knowledge competencies obtained in class V. Each question has an alternative answer that can be chosen by students ( $a, b, c$, and d) for multiple-choice questions. This test is given once as a post-test. The instrument trials were carried out to ensure that the quality was suitable for use in research. The steps to determine the quality of the feasibility of this instrument are through validity testing with experts/experts, item validity analysis, reliability analysis, differentiation analysis, and difficulty level analysis. Analysis of the data used in this study is to use descriptive statistics, which are calculating the average (mean) and then categorized with the Theoretic Ideal Reference Assessment (PAIT) to determine the category of Social Studies knowledge competency obtained by students in both the experimental and control groups. The competency criteria for students' IPS knowledge used are as shown in table 3.

Tabel 3. Scale Five with Ideal Theoretic Reference Assessment (PAIT)

\begin{tabular}{ccc}
\hline No. & Criteria & Classification \\
\hline 1. & $M_{i}+1,5 \mathrm{SD}_{\mathrm{i}} \leq \mathrm{M} \leq \mathrm{M}_{\mathrm{i}}+3,0 \mathrm{SD}_{\mathrm{i}}$ & Very high \\
2. & $\mathrm{M}_{\mathrm{i}}+0,5 \mathrm{SD}_{\mathrm{i}} \leq \mathrm{M}<\mathrm{M}_{\mathrm{i}}+1,5 \mathrm{SD}_{\mathrm{i}}$ & High \\
3. & $\mathrm{M}_{\mathrm{i}}-0,5 \mathrm{SD}_{\mathrm{i}} \leq \mathrm{M}<\mathrm{M}_{\mathrm{i}}+0,5 \mathrm{SD}_{\mathrm{i}}$ & Adequate \\
4. & $\mathrm{M}_{\mathrm{i}}-1,5 \mathrm{SD}_{\mathrm{i}} \leq \mathrm{M}<\mathrm{M}_{\mathrm{i}}-0,5 \mathrm{SD}_{\mathrm{i}}$ & Low \\
5. & $\mathrm{M}_{\mathrm{i}}-3,0 \mathrm{SD}_{\mathrm{i}} \leq \mathrm{M}<\mathrm{M}_{\mathrm{i}}-1,5 \mathrm{SD}_{\mathrm{i}}$ & Very low
\end{tabular}

(Source: Koyan, 2011:116) 
In addition, data analysis also used inferential statistics in the form of prerequisites including normality test data distribution using the normality test in research can be done manually with ChiSquare analysis or with the help of SPSS 22.0 for windows program in the Kolmogorov-Smirnov and Shapiro-Wilk tests, and Homogeneity variance test using the F-test and polled variance t-test to find out the truth of the hypothesis of the difference in the mastery of Social Studies knowledge competence between students in the experimental group and students in the control group who were given different treatment.

\section{Result and Discussion}

This study aimed to determine the significant influence of Tat Twam Asi Role-Playing learning models on mastery of Social Studies knowledge competencies of fifth-grade elementary school students. This research was conducted in the Cluster IV Public Schools in Buleleng District, Buleleng Regency as the study population using two research samples, namely SD Negeri 1 Banyuasri as the Experiment group and Banyuasri SD Negeri 5 as the Control group. The data collected and analyzed were competency data on Social Studies knowledge of fifth-grade students of the Cluster IV Public School in Buleleng District in the cognitive domain in the form of scores. Data obtained from the posttest that has been given in this study. The instrument used for the post-test fulfills the requirements of an instrument by conducting expert tests, validity, reliability, difficulty levels, different power, and instrument trials. The post-test that has been done is given multiple choice questions with 30 items representing representatives of each indicator in learning. Before carrying out the post-test, the study sample conducted a learning process meeting eight times in two themes. The meeting was conducted by giving treatment to the experimental group by implementing the learning process using the RolePlaying learning model based on Tat Twam Asi and there was no special treatment in the control group or only carrying out the learning process using conventional learning models. The number of students analyzed in this study was 35 students in the experimental group and 32 students in the control group. The results of the post-test that have been conducted on the analyzed sample are described as follows.

Tabel 4. Rangkuman Statistik Deskriptif Post-Test Skor Kompetensi Pengetahuan IPS Kelompok Eksperimen dan Kelompok Kontrol

\begin{tabular}{ccc}
\hline \multirow{2}{*}{ Statistik Deskriptif } & \multicolumn{2}{c}{ Kompetensi Pengetahuan IPS } \\
& Kelompok Eksperimen & Kelompok Kontrol \\
\hline $\mathrm{N}$ & 35 & 32 \\
Mean & 81,97 & 70,09 \\
Median & 82,1 & 70,5 \\
Modus & 82,8 & 72,8 \\
Standar Deviasi & 5,23 & 5,59 \\
Varians & 27,32 & 31,25 \\
Range & 24 & 21 \\
Minimum & 70 & 60 \\
Maximum & 93 & 80 \\
\hline
\end{tabular}

Based on table 4. data about the mastery of students' knowledge competence for social studies subjects using Role-Playing learning model based on Tat Twam Asi at the time of posttest with $\mathrm{n}=35$, obtained an average of 81.97, median $=82.1$, mode $=82.8$, maximum value $=93$, minimum value $=70$, span $=24$, many classes are 6 , and class length is interval 4 . While data on the competency of social science knowledge of students learning using conventional models with $\mathrm{n}=32$, obtained an average of average $=70.09$, median $=70.05$, mode $=72.8$, maximum value $=80$, minimum value $=60$, span $=21$, many classes $=6$, and class length $=4$. In addition, social science knowledge competency data in the experimental class and the control class of Class V students of Cluster IV State School, Buleleng District, Buleleng Regency Academic Year 2019/2020 can be presented in the bar graph in Figure 01 below. 


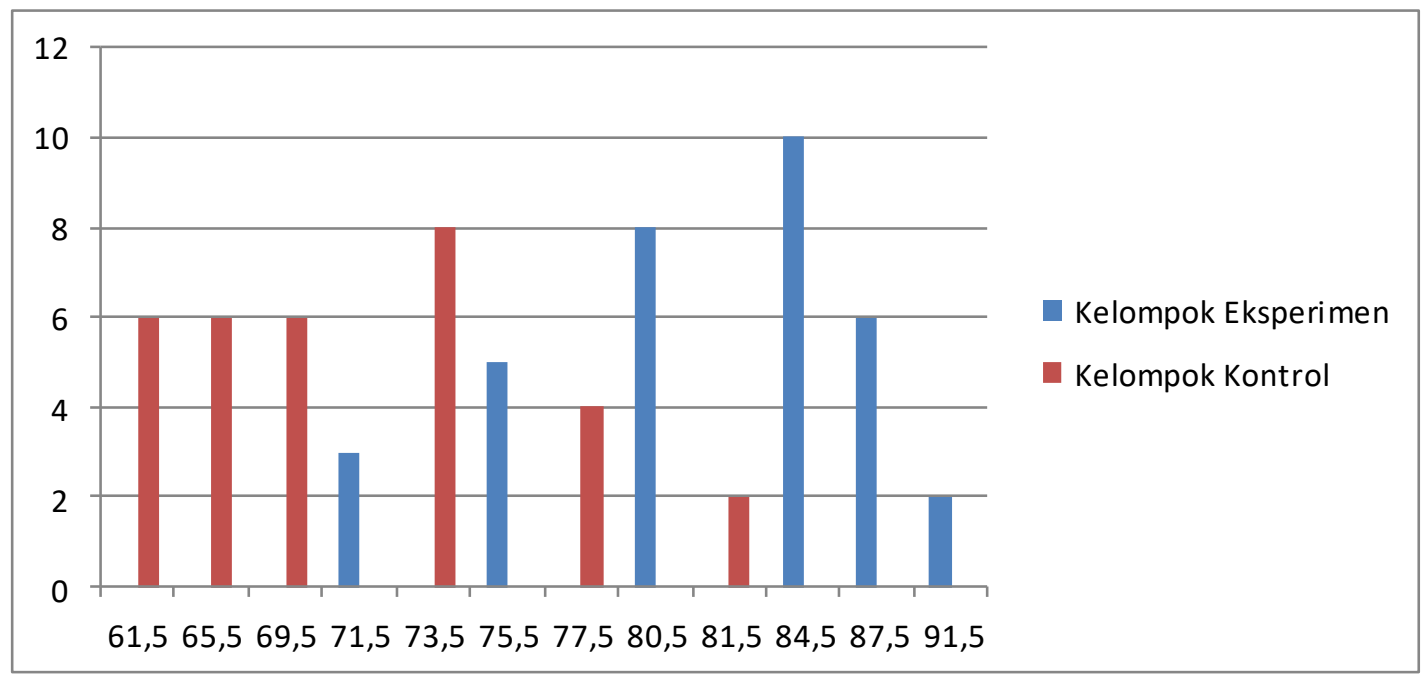

Figure 01

Histogram of IPS Knowledge Competence in Experiment Class and Control Class of Class V Students of Cluster IV Public Schools, Buleleng District, Buleleng Regency Academic Year 2019/2020

In the histogram 1 picture, it can be seen that 3 students have grades of 70-73, 5 students have grades between 74-77, 8 students have grades between 78-81, 10 students have grades between $82-$ 85, 6 students have a value between 86-89, and 3 students have grades between 90-93. In the control class, it can be seen that 6 students have grades between $60-63,6$ students have grades between 6467, 6 students have grades between 68-71, 8 students have grades between 72-75, 4 students have grades between 76-79, and 2 students have grades between $80-83$. To find out the quality of IPS knowledge competency variables in the experimental class and the control class, the average value of the IPS knowledge competence of students is converted into the Five Scale Classification Scale Theoretical Reference Assessment category to produce a conversion table as in table 5 below.

Table 5. Social Sciences Competency Data Categories of Students Following the Tat Twam Asi Based Role-Playing Learning Model

\begin{tabular}{cccc}
\hline No. & Kriteria & Rentang Nilai & Klasifikasi \\
\hline 1 & $M_{i}+1,5 S D_{i} \leq M_{i}+3,0 S D_{i}$ & $75 \leq \bar{X} \leq 100$ & Very high \\
2 & $M_{i}+0,5 S D_{i} \leq M_{i}+1,5 S D_{i}$ & $58 \leq \bar{X} \leq 75$ & High \\
3 & $M_{i}-0,5 S D_{i} \leq M_{i}+0,5 S D_{i}$ & $42 \leq \bar{X} \leq 58$ & Adequate \\
4 & $M_{i}-1,5 S D_{i} \leq M_{i}-0,5 S D_{i}$ & $25 \leq \bar{X} \leq 42$ & Low \\
5 & $M_{i}-3,0 S D_{i} \leq M_{i}-1,5 S D_{i}$ & $0 \leq \bar{X} \leq 25$ & Very low \\
\hline
\end{tabular}

The results of the data analysis description obtained that the average value of the competence of social science knowledge of the experimental group students, with $M=81.97$ is categorized into the Five Scale with the Theoretic Ideal Reference Assessment (PAIT) included in the "Very High" category. Meanwhile, the average value of the competence of social studies students' knowledge of the control group, with $M=70.09$ is categorized into the Five Scale with the Theoretic Ideal Reference Assessment (PAIT) is classified as a "High" criterion. This indicates that the average value of the competence of students' social science knowledge taught using the Tat Twam-based Role-Playing learning model is higher than that of students who are taught using conventional learning models.

After analyzing the data with descriptive statistics, the analysis phase with inferential statistics is the prerequisite test and $t$-test to test the hypothesis. The first prerequisite test is the normality test tested using Chi-Square analysis. The calculation results are as follows.

Table 6. Summary of Normality Test Calculations

\begin{tabular}{clllll}
\hline No. & \multicolumn{1}{c}{ Group of Data } & & $\boldsymbol{X}_{\text {hitung }}^{2}$ & $\boldsymbol{X}_{\text {tabel }}^{2}$ & Information \\
\hline 1 & $\begin{array}{l}\text { Knowledge competence of experimental } \\
\text { group IPS }\end{array}$ & 6 & 6,55 & 7,81 & Normal
\end{tabular}


Based on table 6, the results of the analysis obtained normality knowledge competency test results of IPS knowledge in the experimental group is $X_{\text {hitung }}^{2}=6,556$ with $X_{\text {tabs }}^{2}$ a significance level of $5 \%$ and $\mathrm{dk}=3$ is 7,815 . This means $X_{\text {hitung }}^{2}$ the knowledge competency of the experimental group IPS is smaller than $X_{\text {tabel }}^{2}(6,556<7,815)$ so that the knowledge competency data of the experimental group is normally distributed. In the control group's IPS knowledge competency data is obtained $X_{\text {hitumg }}^{2}=$ 7,568 and with $X_{\text {tabel }}^{2}$ a significance level of $5 \%$ and $\mathrm{dk}=3$ is 7,815 . This means $X_{\text {hitung }}^{2}$ the control group's IPS knowledge competency is smaller than $X_{\text {tabsi }}^{2}(7,568<7,815)$, so the control group competency IPS knowledge data is normally distributed.

Homogeneity tests were then performed on the pair variance between the experimental and control groups. The test used is the F-test with homogeneous data criteria if Fcount $<$ Ftable. The summary of the results of the homogeneity of the variance between the experimental and control groups is presented in table 7 below.

Table 7. Recapitulation of Variance Homogeneity Test Results with the F-Test

\begin{tabular}{|c|c|c|c|c|c|c|c|}
\hline \multirow{2}{*}{ No. } & \multirow[t]{2}{*}{ Data Group } & \multirow{2}{*}{ Variants $\left(S^{2}\right)$} & \multicolumn{3}{|c|}{$\mathbf{F}_{\text {co }}$} & \multirow[t]{2}{*}{$\mathbf{F}_{\mathbf{t a}}$} & \multirow{2}{*}{ Information } \\
\hline & & & unt & & ble & & \\
\hline 1 & $\begin{array}{l}\text { Knowledge competence of } \\
\text { experimental group IPS }\end{array}$ & 27,32 & & \multirow{2}{*}{1,1} & \multirow[b]{2}{*}{99} & \multirow{2}{*}{3 , } & \multirow{2}{*}{ Homogenous } \\
\hline 2 & $\begin{array}{l}\text { Knowledge competency of } \\
\text { control group IPS }\end{array}$ & 31,25 & 4 & & & & \\
\hline
\end{tabular}

Based on table 7 , it is known that the $\mathrm{F}$ count of the knowledge competency of the experimental class and control class IPS $=1.14$, while the $\mathrm{F}$ table at the $5 \%$ significance level is 3.99 . So, the value of $\mathrm{F}$ table is greater when compared to F count (F count (1.14) <F table (3.99)), so H0 is accepted and it can be concluded that the variance of IPS knowledge competency data in the experimental class and the control class is homogeneous.

Based on the results of the normality test of data distribution and the homogeneity test of variance it is known that the data obtained by the experimental and control groups are normally distributed and have a homogeneous variance. Because the data obtained meets the prerequisites, the hypothesis test can be performed using the t-test polled variance test. The results of the analysis of the t-test polled variance test from the mastery competency data of students' social science knowledge are presented in table 8 as follows.

Table 8. Summary of Analysis Results of the T-Test Polled Variance Test

\begin{tabular}{|c|c|c|c|c|c|c|c|c|c|}
\hline No & Sample & Average & Variants & $\mathrm{k}$ & & $\mathrm{N}$ & T-count & T-table & $\begin{array}{l}\text { Conclusi } \\
\text { on }\end{array}$ \\
\hline 1 & $\begin{array}{l}\text { Experimentation } \\
\text { Class }\end{array}$ & 81,97 & 27,32 & & & 35 & 8,99 & 399 & \\
\hline 2 & Control class & 70,09 & 31,25 & 5 & 32 & & & & rejected \\
\hline
\end{tabular}

Based on table 8, the results of the analysis of the t-test polled variance test, obtained $\mathrm{t}$-count $=$ 8.99 , while t-table with $\mathrm{dk}=65$ at a significance level of $5 \%=3.99$, so the results of the analysis state that $\mathrm{t}$-count is greater than $\mathrm{t}$-table ( $\mathrm{t}$-count $=8.99>$ table 3.99 ), so H0 is rejected and H1 is accepted. So, it can be concluded that there is an influence of social science knowledge competence between students who take the Tat Twam Asi based Role-Playing learning model and students who take conventional learning in class V students of Cluster IV State Schools, Buleleng District, Buleleng Regency, 2019/2020 Academic Year.

First, the Role-Playing learning model is one of the group learning models that invite students to play roles in accordance with the play scripts prepared by the teacher. The Role-Playing learning model is one of the mastery models of learning materials through the development of the imagination and 
appreciation of students in the world of education (Subagiyo, 2013). According to Widnyana, et al (2017) Role-Playing is a type of motion game that has goals, rules, and edutainment. According to Shoimin (2014) the advantages of Role-Playing learning models are: 1) can understand events that take place easily and can pick the points of wisdom contained in it with the appreciation of students themselves, 2) play activities are activities that are easy to use in some situations that different, 3) the teacher's evaluation can be observed by observing when students are implementing the game, 4) students are free to make decisions and express themselves in full, 5) activities can attract students so that the class becomes active, 6) have long-lasting memory on students, 7 ) foster self-confidence and a sense of solidarity and high social solidarity, and 8) it is possible to improve students' professional abilities and can foster/open opportunities for employment. Furthermore, the advantage of RolePlaying models according to Djamarah (2013) is that it can train students to understand and remember the contents of the material being played, students will practice to initiate and be creative, the talent contained in students can be fostered so that it is possible to emerge or grow the seeds of drama art in school, cooperation between players can be fostered and fostered as well as possible, students get the habit of accepting and sharing responsibility with others, the students' spoken language can be fostered into a better language so that it is easily understood by others. Based on this, the Role-Playing learning model can make students active and support students to have good social attitudes.

This is also supported by previous research conducted by (1) Budi (2016) there is a positive influence on the social attitudes of groups of students who take a role-playing learning model assisted by the media in Bali compared to groups of students who take conventional learning and there is a positive influence on understanding concepts PPKn between groups of students who took the RolePlaying learning model assisted by one and two bali media compared to groups of students who took conventional learning, (2) research conducted by Evie (2017) the use of Role-Playing models assisted by media masks influenced the mastery of fifth grade Social Studies knowledge competencies SDN Cluster Tuanku Imam Bonjol, West Denpasar District, (3) research conducted by Lestari (2019) RolePlaying learning model assisted by concrete media influences the competency of Social Studies knowledge of fourth grade elementary school clusters III students in North Kuta District 2018/20/2012 Academic Year 19, and (4) Research conducted by Widnyana, et al (2017) on the fourth grade students of the Untung Surapati cluster in East Denpasar District in the 2016/2017 school year there was an influence of the Role-Playing learning model based on Tri Hita Karana on the Social Studies competence of fourth grade elementary school students Untung Surapati Cluster East Denpasara District 2016/2017 Academic Year. Based on previous research that has been done, it can be concluded that the Role-Playing model has a significant influence on the mastery of students' Social Studies knowledge competence

Second, in Hinduism teaches the value of Tat Twam Asi. Meaning: I am you, you are me. In Sanskrit according to Juniani (2019), Tat Twam Asi consists of 3 syllables namely: 1) that is derived from the word tad which means it or him, 2) tvam is derived from the word yusmad means you, and 3) asi comes from the word as (a) the meaning is, so the Tat Twam Asi is I am you or you are me in the learning process we are required to respect each other with differences. In line with this, Pradnyani, et al (2017) state that Tat Twam Asi is the teaching of equality in human dignity which means that all human beings are born with the same dignity so that humans must love each other, respect each other, respect each other, and help each other. In addition, the teachings of Tat Twam Asi can make students more socially minded and willing to help their friends in understanding learning material, if there are difficulties then students who can help students who have less ability. This is also supported by the opinion of Adanyana, et al (2017) that the teaching of Tat Twam Asi in the learning process makes all students active so that learning becomes fun because students are invited to play roles and each student is also given the opportunity as freely as possible to improvise the scenario text that has been created by the teacher in his appearance with his friend so that students can express a role they play. The concept of Tat Twam Asi in the learning process can help students to behave better towards their friends, teachers, and others and assume all are siblings and can develop their own potential.

Third, based on the results of research that has been done there is a positive effect. The positive influence is caused by Tat Twam Asi based Role-Playing learning model making learning fun, students becoming more active, increasing the mentality of students who always hold fast to the teaching of Tat Twam Asi if this is related to social studies learning, social studies learning is expected to make a pleasant atmosphere for students has been achieved optimally and integrated social studies learning has been able to play a role to encourage mutual understanding between human beings, and the focus of attention on human relations with social understanding (Parbawa, et al, 2018). Social studies learning by using Tat Twam Asi based Role-Playing learning models has been able to help students to 
understand and adjust themselves to the changes that often occur in society (Santiasih, 2016). This is supported by the opinion of Shoimin (2014) regarding Role-Playing learning models that make students play a role to increase student awareness of the values contained in a manuscript text. Thus, research findings obtained mastery of different knowledge competencies in the experimental group and the control group. The difference in the mastery of knowledge competencies found is also supported by the opinion according to Shoimin (2014) about the advantages of Role-Playing learning models, namely: 1) can understand events that take place easily and can pick the points of wisdom contained in it with the appreciation of students themselves, 2) play activities are activities that are easy to use in several different situations, 3) evaluations can be made by the teacher observing when students are implementing the game, 4) students are free to make decisions and express themselves in full, 5) activities can attract students so that the class becomes active, 6 ) has a long-lasting memory on students, 7) fosters self-confidence and a sense of solidarity and social solidarity, and 8) is possible to improve students' professional abilities, and can foster/open opportunities for employment. Furthermore, the advantage of Role-Playing models according to Djamarah (2013) is that it can train students to understand and remember the contents of the material being played, students will practice to initiate and be creative, the talent contained in students can be fostered so that it is possible to emerge or grow the seeds of drama art in school, cooperation between players can be fostered and fostered as well as possible, students get the habit of accepting and sharing responsibility with others, the students' spoken language can be fostered into a better language so that it is easily understood by others. Thus, this Role-Playing learning model based on Tat Twam Asi has an influence on the learning process and outcomes.

This study was also strengthened by research conducted by Adnyana, et al (2017) with the title influence of the Role-Playing learning model based on Tat Twam Asi on the Social Studies competence of fifth-grade students at SD Negeri Gugus Budi Utomo Academic Year 2016/2017. States the Tat Twam Asi Based Role-Playing learning model influences the mastery of IPS knowledge competencies. Research conducted by Pradnyani, et al (2017) in fourth-grade students of the PB Cluster Elementary School. Sudirman Denpasar Barat Academic Year 2016/2017 using Quantum learning based on local wisdom Tat Twam Asi affects the competency of PKN student knowledge supports that the use of Tat Twam Asi in learning can improve the expected knowledge competence and the changes in student behavior towards better.

Based on the results of research and supporting research it can be said that there is an influence of Tat Twam Asi Based Role-Playing learning model on the mastery of students' Social Studies knowledge competence. This is inseparable from the advantages of the Role-Playing model itself and the strengths of the teachings of Tat Twam Asi. The combination of this model has a positive effect on the conditions of student learning that leads students to always be active, willing to talk to give opinions and the objectives of learning can be achieved.

\section{Conclusion}

Based on the analysis of the data that has been done, the results of the analysis of the polled variance $\mathrm{t}$-test are $\mathrm{t}$-count of 8.99 , while the table with $\mathrm{dk}=65$ at a significance level of $5 \%$ is 3.99 , so from the analysis results that the $\mathrm{t}$-count is greater than the table ( $\mathrm{t}$-count $=8.99>$ table 3.99 ), so $\mathrm{H0}$ is rejected and $\mathrm{H} 1$ is accepted. Furthermore, students who followed the Role-Playing learning model based on Tat Twam Asi obtained an average higher $=81.97$ than students who took conventional learning which only gained an average value $=70.09$. This means that learning using the Role-Playing learning model based on Tat Twam Asi affects the mastery of social science knowledge competencies in fifth-grade students of Cluster IV State School, Buleleng District, Buleleng Regency, Academic Year 2019/2020.

Based on the conclusions above can be submitted suggestions based on research that has been done are as follows: (1) the results of this study state that students who learn to use the Role-Playing learning model based on Tat Twam Asi have mastery of Social Studies knowledge competence higher than students who take part significant conventional learning, so that this model should be able to be used and developed to teachers to create a more pleasant learning atmosphere and provide maximum learning outcomes, (2) teachers are advised to apply the Role-Playing learning model based on Tat Twam Asi because the results of research prove that the use of Role-Playing learning models based on Tat Twam Asi is able to improve the mastery of Social Studies knowledge competencies of students and can increase the attitude of tolerance, mutual respect, and mutual assistance between students who will have an impact on social life, (3) It is hoped that the results of this study can be used by school principals as a guideline in guiding teachers to carry out the learning process using learning models 
that are able to increase the competency of students' knowledge, and (4) for other researchers so that the results in this study can be used as a library guide to conduct research on the same variable or on different variables.

\section{References}

Adhi, M. K. 2016. “Tat Twam Asi: Adaptasi Nilai Kearifan Lokal Dalam Pengentasan Kemiskinan Kultural”. Seminar Nasional Riset Inovatif, Denpasar. Pp (581- 594).

Adnyana, dkk. 2017. "Pengaruh Model Pembelajaran Role-Playing Berbasis Tat Twam Asi Terhadap Penguasaan Kompetensi Pengetahuan IPS". International Journal of Elementarary Education. Vol. 2, No. 2 (hlm 87-93).

Antari, dkk. 2017. "Pengaruh Model Pembelajaran Kooperatif tipe Two Stay Two Stray (TSTS) berbantuan Multimedia terhadap Kompetensi Pengetahuan IPS Siswa Kelas V SD Gugus Letda Made Putra". E-Journal PSGD Universitas Pendidikan Ganesha. Vol. 5, No. 2 (hlm. 3).

Astami, dkk. 2016. "Penerapan Inkuiri Terbimbing Berbasis Tri Hita Karana Dapat Meningkatkan Sikap Sosial dan Kompetensi Pengetahuan IPS". E-journal PGSD Universitas Pendidikan Ganesha. Vol 4, No. 1 (hlm. 2).

Basri, Hasan. 2017. "Penerapan Model Pembelajaran Role-Playing Untuk Meningkatkan Hasil Belajar Bahasa Indonesia Siswa Kelas V SDN 032 Kualu Kecamatan Tambang”. Jurnal Pendidikan dan Pengajaran Program Studi Pendidikan Guru Sekolah Dasar FKIP Universitas Riau. Vol.1, No. 3 (hlm. 2728-2740).

Budi, Astawa I Gusti Kade. 2016. "Pengaruh Model pembelajaran Role-Playing Berbantuan Satua Bali Terhadap Sikap Sosial Dan Pemahaman Konsep Siswa Kelas V SD Gugus XV Kecamatan Buleleng". Jurnal PGSD. Vol 4, No. 1 (hlm. 1-11).

Dantes, Nyoman. 2017. Metodologi Penelitian. Singaraja: Universitas Pendidikan Ganesha.

Dewi, Tiara. 2017. "Efektivitas Model Role-Playing Dalam Meningkatkan Kompetensi Mahasiswa Pada Mata Kuliah Manajemen Keuangan Jurnal Pendidikan Ekonomi UM Metro". FKIP Ummetro. Vol. 5.

Djamarah, dkk. 2013. Strategi Belajar Mengajar. Jakarta: PT. Rineka Cipta.

Emin, Kilinc. 2014. “Pre-Service Social Studies Teachers' Understandings About The Nature Of The Social Studies". International Electronic Journal of Elementary Education. Vol. 6, No. 3.

Evie, Febrianti Ni Kadek. 2017. “Pengaruh Model Pembelajran Role-Playing Berbantuan Media Topeng Terhadap Kompetensi Pengetahuan IPS Siswa Kelas V SDN Gugus Tuanku Imam Bonjol Kecamatan Denpasar Barat". Jurnal Mimbar PGSD. Vol 5, Nomor 2 (hlm. 1-10).

Indrawan, dkk. 2017. "Pengaruh Model Pembelajaran Think Talk Write berbasis Tri Hita Karana terhadap Kompetensi Pengetahuan IPS". E-Journal PGSD Universitas Pendidikan Ganesha. Vol. 5, No. 2 (hlm. 2-3).

Juniani, Made. 2019. Pendidikan Agama Hindu dan Budi Pekerti. Bali: Media Abadi.

Koyan, I Wayan. 2011. Buku Ajar 2007: Statistik Dua: Analisis Varian, Kovarians dan Jalur. Singaraja: Universitas Pendidikan Ganesha Press.

Kristin, F. 2018. "Meta-Analisis Pengaruh Model Pembelajaran Role-Playing terhadap Hasil Belajar IPS". Jurnal Refleksi Edukatika. Vol. 8, No. 2 (hlm. 172).

Kurniasih, Imas. 2017. Ragam Pengembangan Model Pembelajaran Untuk Peningkatan Profesionalitas Guru. Jakarta: Kata Pena.

Leonari, dkk. 2018. "Pengaruh Model Pembelajaran Picture and Picture Berbasis Karakter terhadap Kompetensi Pengetahuan IPS". Journal for Lesson and Learning Studies. Vol. 1, No. 2 (hlm 7480).

Lestari, Ani Ela Ayu I Gusti. 2019. "Pengaruh Model Pembelajran Role-Playing Berbantuan Media Konkret Terhadap Kompetensi Pengetahuan PPKn Siswa Kelas IV SD Gugus III Kecamatan Kuta Utara". Jurnal Mimbar PGSD. Vol 7, Nomor 2 (hlm. 5-10). 
Mardalena, Dwi. 2018. "Penerapan Model Pembelajaran Role-Playing Untuk Meningkatkan Hasil Belajar IPA Siswa Kelas VI Sekolah Dasar". Jurnal Primary Program Studi Pendidikan Guru Sekolah Dasar Universitas Riau. Vol. 7.

Meiyani, dkk. 2017. "Pengaruh Model Quantum Teaching melalui Karyawisata terhadap Penguasaan Kompetensi Pengetahuan IPS Siswa Kelas V”. E-Journal PSGD Universitas Pendidikan Ganesha. Vol. 5, No. 2 (hlm. 2-3).

Mulyadi. 2011. Sistem Perencanaan dan Pengendalian Manajemen. Jakarta: Salemba Empat.

Mulyani, Novi. 2016. Dasar-Dasar Pendidikan Anak Usia Dini. Yogyakarta: Kalimedia.

Nurbiyanti, dkk. 2017. "Keefektivan Penerapan Model Role-Playing dan Paired Storytelling terhadap Aktivitas dan Hasil Belajar IPS”. Journal of Primary Education. Vol. 6, No. 1 (hlm. 57-64).

Parbawa, I Gusti Ngurah Made Anom, dan I Wayan Sujana. 2018. "Pengaruh Model Pembelajaran Visual Auditory Kinestetik dan Motivasi Belajar Terhadap Kompetensi Pengetahuan IPS Siswa Kelas IV". Jurnal Ilmiah Sekolah Dasar. Vol 2, No. 1 (hlm. 70).

Pradnyani, dkk. 2017. "Pengaruh Pembelajaran Quantum Berbasis Kearifan Lokal Tat Twam Asi Terhadap Kompetensi Pengetahuan PKN Siswa Kelas IV SD Gugus PB. Sudirman Denpasar Barat Tahun Pelajaran 2016/2017". International Journal of Elementarary Education. Vol. 1, No. 4 (hlm 287-288).

Rahmawati, dkk. 2016. "Pengaruh Pendekatan Saintifik Berbasis Portofolio Terhadap Penguasaan Kompetensi Pengetahuan IPS Ditinjau Dari Kepercayaan Diri”. E-journal PGSD Universitas Pendidikan Ganesha. Vol 4, No. 1 (hlm. 2).

Riduwan. 2011. Rumus dan Data dalam Aplikasi Statistika Edisi Pertama. Bandung: Alfabeta.

Santiasih, dkk. 2016. "Penerapan Talking Stick dalam Pendekatan Saintifik untuk Meningkatkan Penguasaan Kompetensi Pengetahuan IPS dan Motivasi Belajar Siswa Kelas IV SD N 9 Padang Sambian”. E-Journal PGSD Universitas Pendidikan Ganesha. Vol. 4, No. 1 (hlm. 2).

Setiana, Nana. 2014. "Pembelajaran IPS Terintegrasi Dalam Konteks Kurikulum 2013". Journal Edu Humaniora. Vol. 6, No. 2 (hlm 96).

Shoimin, Aris. 2014. Model Pembelajaran Inovatif dalam Kurikulum 2013. Yogjakarta: Ar-Ruzz Media.

Subagiyo, Heru. 2013. Role Play. Jakarta: Kementerian Pendidikan dan Kebudayaan Direktorat Pembinaan Sekolah Menengah Kejuruan.

Sugiyono. 2014. Metode Penelitian Pendidikan. Bandung: Alfabeta.

Surahman, Edi dan Mukminan. 2017. "Peran Guru IPS Sebagai Pendidik dan Pengajar Dalam Meningkatkan Sikap Sosial Dan Tanggung Jawab Sosial Siswa SMP”. Journal UNY. Vol. 4, No. 1 (hlm. 4).

Trianto. 2012. Model Pembelajaran Terpadu. Jakarta: Bumi Aksara.

Wahyuni, dkk. 2016. "Pengaruh Model Role-Playing Terhadap Kemampuan Komunikasi Matematis Siswa Pada Materi Fungsi Komposisi Kelas XI Sma Negeri 6 Singkawang". Jurnal Pendidikan Matematika Indonesia. Vol. 1, No. 2 (hlm. 81-86).

Widnyana, dkk. 2017. "Pengaruh model pembelajaran Role-Playing berbasis Tri hita karana terhadap kompetensi pengetahuan ips Siswa kelas iv sd gugus untung surapati Kecamatan Denpasar Timur Tahun pelajaran 2016/2017". E-Journal Universitas Pendidikan Ganesha. Vol. 5, No. 2 (hlm 2-9). 